\title{
定ひずみねじり疲労強度と定ひずみ引張圧縮
}

\author{
疲労強度との比較*
}

楠本 韶** 竹内守**

\section{Comparison of Constant Strain Fatigue Tests by Torsion and by Tension-Compression}

by

\section{Shō Kusumoto and Mamoru Takeuchi}

(Hitachi Research Laboratory Hitachi Ltd., Hitachi)

The constant strain fatigue tests by tension-compression and by torsion were carried out in room temperature with the use of $18 \mathrm{Gr}-8 \mathrm{Ni}$ stainless steel and mild steel cylindrical hollow specimens, in which the relations between the effective stress range, the effective strain range and the cycles to crack were studi id.

No essential influence was found on these relations resulting from the difference of the two test methods, torsion and tension-compression. Similar results were obtained as to the relations between the strain range and the cycles to crack when the maximum shear strain range was used instead of the effective strain range.

The effect of the thickness of the specimens on the cycles to crack was also studied in the torsional constant strain fatigue tests in which the cycles to crack $N_{f}$ were judged from the sudden reduction of the torque range. The results show that the $N_{f}$ increase with the thickness of the specimens when the outer diameters were kept constant $(16 \mathrm{~mm})$, and that the $N_{f}$ of the cylindrical solid specimen is almost doubled in comparison with that of the hcllow specimen of thickness $1 \mathrm{~mm}$ under the same strain range.

(Received May 8, 1964)

\section{1 緒言}

多軸応力下の定ひずみ疲労や熱疲労が問題となるて とはしばしばあり，その際の強度については有効ひず みを用いれば単軸応力下の疲労破壊法則がそのまま適 用されると一応考光られるが，乙れを実験的に確かめ た例は非常に少ないので, 是非確かめておく必要があ る。また，実験設備や実験技術の面からみた場合に定 ひずみ疲労あるいは熱疲労の実験を単軸荷重よりも， ねじりによって行なうほうが便利なととがある，以上 の理由から筆者らは引張圧縮とねじりの定ひずみ疲労 試験を行なって，有効ひずみを用いて結果を比較検討 すると同時に，塑性域での問題を取り扱う場合の要素 の一つである最大せん断ひずみによる整理をも行なう こととし，その第 1 段階として室温での実験を行なっ たので，結果を報告する．なお，高温での定ひずみね ヒり疲労試験では試験片表面の酸化や微細な山凸のた めに初期き裂を試験片表面の観察によって発見するの が困難な場合があり，その際にはき裂発生の時期を卜 ルク変化から判定するのが便利と思われるが，てのと きに試験片の肉厚がき裂発生繰返数に及ぼす影響につ

- 原稿受理 昭和39年 5 月 8 日

**（株)日立製作所日立研究所 日立市幸町
いても実験的にたしかめたのであわせて報告する。

$$
2 \text { ひずみと応力 }
$$

\section{$2 \cdot 1$ 有効ひずみと有効応力}

有効ひずみと有効応力はよく知られているように次 式で与えられる.

有効応力

$$
\sigma_{e}=\frac{1}{\sqrt{2}} \sqrt{\left(\sigma_{1}-\sigma_{2}\right)^{2}+\left(\sigma_{2}-\sigma_{3}\right)^{2}+\left(\sigma_{3}-\sigma_{1}\right)^{2}}
$$

有効ひずみ

$$
\varepsilon_{e}=\frac{\sqrt{\frac{1}{2}}}{3} \sqrt{\left(\varepsilon_{1}-\varepsilon_{2}\right)^{2}+\left(\varepsilon_{2}-\varepsilon_{3}\right)^{3}+\left(\varepsilon_{3}-\varepsilon_{1}\right)^{2}}
$$

有効塑性ひずみ

$$
\begin{aligned}
\varepsilon_{p e}=\frac{\sqrt{2}}{3} \sqrt{\left(\varepsilon_{p 1}-\varepsilon_{p_{2}}\right)^{2}+\left(\varepsilon_{p_{2}}-\varepsilon_{p 3}\right)^{2}+\left(\varepsilon_{p 3}-\varepsilon_{p_{1}}\right)^{2}} \\
\text { こてで } \sigma_{1}, \sigma_{2}, \sigma_{3}: \text { 主応力 } \\
\varepsilon_{1}, \varepsilon_{2}, \varepsilon_{3}: \text { 主ひずみ } \\
\varepsilon_{p_{1}}, \varepsilon_{p_{2}}, \varepsilon_{p_{3}}: \text { 主塑性ひずみ }
\end{aligned}
$$

単軸応力およびねじりの場合の $\sigma_{e}, \varepsilon_{p e}$ は次のように なる。

(a) 単軸応力

$$
\left\{\begin{array}{l}
\sigma_{e}=\sigma_{1} \\
\varepsilon_{p e}=\varepsilon_{p_{1}}=\ln \frac{S_{0}}{S}
\end{array}\right.
$$


ただしサイイックス 1 は応力の方向の量を示す、 また， $S_{0}, S$ は引張りまたは圧縮の際の当初および終 わりの断面積である.

(b) ねじり

$$
\left\{\begin{array}{l}
\sigma_{e}=\sqrt{\overline{3}} \tau_{s} \\
\varepsilon_{p_{e}}=\frac{2}{\sqrt{3}} \ln \left(\sqrt{1+\frac{\gamma_{p_{s}}{ }^{2}}{4}+\frac{\mathrm{P}_{p_{s}}}{2}}\right)
\end{array}\right.
$$

こてで $\tau_{s}$ にトルク $T$ と塑性極断面係数 $z_{p}$ とから $\tau_{s}=T / z_{p}$ として求められるせん断応力， $\gamma_{p_{s}}$ は標線 距離 $l$ 間のねじれ 角の塑性成分 $\theta_{p}$ と半経 $r$ とから $\gamma_{p s}=r \theta / l$ として計算されるせん断塑性ひずみである.

\section{$2 \cdot 2$ せん断ひずみ}

こてで用いるせん断ひずみ $\gamma$ は Fig. 1 亿示すよ うに物体内に画加た平面 $\mathrm{AB}$ とそれへの法線 $\mathrm{OA}$

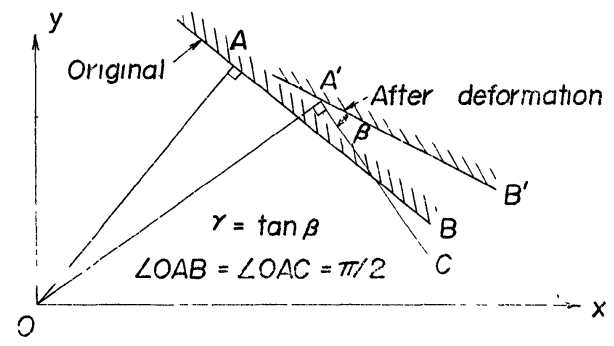

Fig. 1. Definition of shear strain $\gamma$.

とが変形によって $\mathrm{A}^{\prime} \mathrm{B}^{\prime}$ および $\mathrm{OA}^{\prime}$ のようになった ときの $\angle \mathrm{OAB}$ の変化量 $\beta$ の正切 $\tan \beta$ で定義され るものである、単軸応力およびねじりの場合の $\gamma$ は次 のようになる。

(a) 単軸応力

$\mathrm{x}$ 軸を引張りの方向にとれば

$$
\gamma=\frac{1}{2}\left(\sqrt{\frac{i_{x}}{\gamma_{y}}}-\sqrt{\frac{\bar{\lambda}_{y}}{\lambda_{x}}}\right) \sin 2 \alpha
$$

ただし

$$
\begin{aligned}
& j_{x}=\left(1+\varepsilon_{x}\right)^{2} \\
& i_{y}=\left(1+\varepsilon_{y}\right)^{2} \\
& \varepsilon_{x}, \varepsilon_{y}: x, y \text { 軸方向のひずみ }
\end{aligned}
$$

丸棒試験片では当初の直経を $D_{0}$, 変形後の直経を $D$ とすれば

$$
\gamma=\frac{1}{2}\left\{\left(\begin{array}{c}
D_{0} \\
D
\end{array}\right)^{3}-\left(\begin{array}{c}
D \\
D_{0}
\end{array}\right)^{3}\right\} \sin 2 \alpha
$$

$\gamma$ は $\alpha=\frac{\pi}{4}$ のときに最大となって

$$
\gamma_{\max }=\frac{1}{2}\left\{\left(\frac{D_{0}}{D}\right)^{3}-\left(\frac{D}{D_{0}}\right)^{3}\right\}
$$

(b) ねじり

$\mathrm{x}$ 軸を単純せん断のせん断方向にとれば

$$
\gamma=\gamma_{s} \cos 2 \alpha+\frac{\gamma_{s}^{2}}{2} \sin 2 \alpha
$$

$\gamma$ は $\tan 2 \alpha=\frac{\gamma_{s}}{2}$ のときに最大となって

$$
r_{\max }=r_{s} \sqrt{1+\frac{r_{s}^{2}}{4}}
$$

$$
3 \text { 実験 }
$$

\section{3・1 試験機および試験片}

ねじり試験機は自動繰返しねじりが可能な島津製 RET 300 型ねじり試験機を用いた。 また，引張圧縮 にはひずみ振幅が小さい範囲では東京試験製の熱疲労 試験機を，ひずみ振幅が大きい範囲ではアムスラ型引 張試験機を用いた，Fig. 2 は本実験に用いた試験片で ある、ねじりの標準試験片としては同図の I 型試験片 を用いたが一部の実験にはII型を，また，肉厚の影響 をみると実験にはIII型片を使用した。試験片の外表面 は旋盤仕上げ，内面はリーマー仕上げである．ひずみ が大きい範|用ではねじり座届を防ぐために試験片内孔
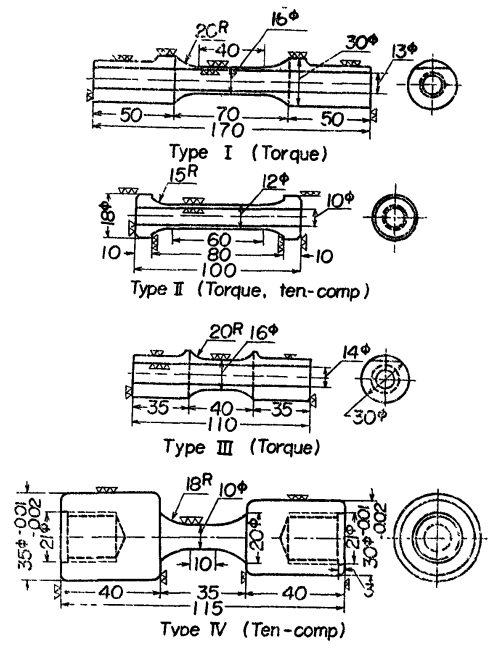

Fig. 2. Specimens.
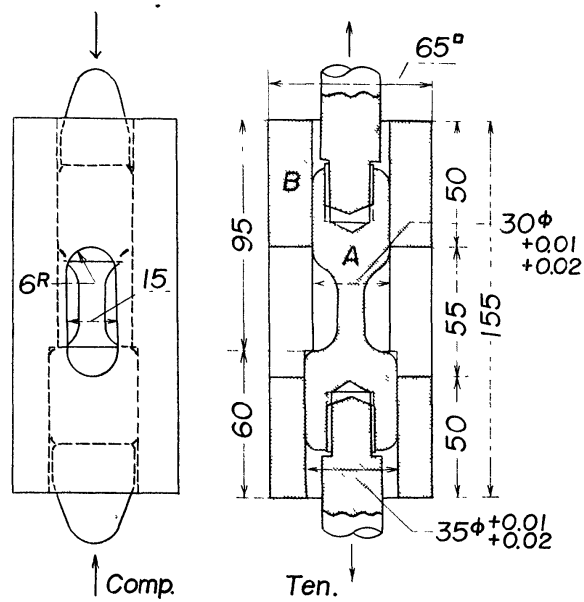
A: Type $\pi$ specimen B: Attachment

Fig. 3. Attachment of large strain range ten.-comp. test. 
に直径が内孔より約 $0.2 \mathrm{~mm}$ 小さい丸棒を挿入した。 引張圧縮の多くは而型試験片を用いて行なったが，ひ ずみがとくに大きい場合には IV 型試験片を 用いた。

Fig. 3 亿示すように IV型試験片では試験片のつかみ 部が角鋼に丸穴をあけてつくった治具に滑合された状 態で試験されるので圧縮の際に座屈が起とりにくい， 同試験片の引張りは同図に示すように，つかみ部にね じ込んだボルトを介して行なった。

\section{3 ・ 2 ひずみの測定}

ねじり試験では Fig. 4 のように標線位置の一つに 目盛をつけ，他の一つに取り付けた指針の目盛上での 動きから標線間のねじれ角 $\theta$ を測定した。また，引張

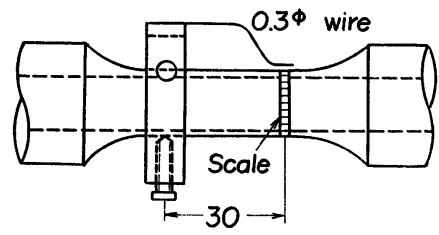

Fig. 4. Attachment to measure torque angle.

圧縮試験では標線間の長さ変化を望遠鏡で読み取って ひずみを算出した．ただ，ひずみが大きいIV型試験片 では局部的な直径変化が生じてひずみ分布が軸方向に 一様でなくなるので，サイクル中の直径変化が最も大 きい断面での直径をマイクロメータで測定してひずみ を求めた。

\section{$3 \cdot 3$ 材 料}

材料は SS 41 および SUS 27 を用いた。化学成分 および，熱処理条件は Table I I 機械的性質はTable
IIに示すとおりである，材料の異方性については検討 しなかった。

\section{$4 \cdot 1$ 繰返数亡応力}

\section{実験結果と検討}

Fig. 5 はSS 41 および SUS 27 亿いての繰返し ねじり試験わよび弓張圧縮試験における繰返数 $N$ と
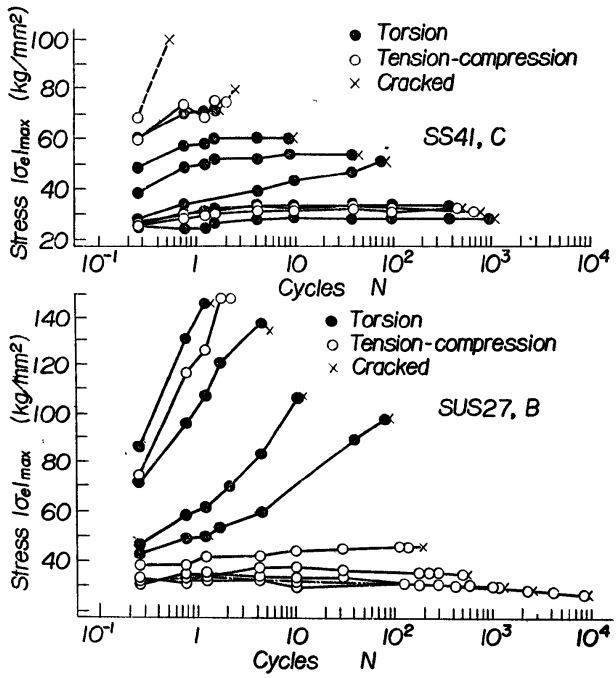

Fig. 5. Variation of $\left|\sigma_{e}\right|_{\max }$ during the tests. 応力との関係である。乙れらの図では $N=1 / 4,3 / 4$, $5 / 4 \cdots$ に対応する応力，すなわちひずみと応力との関 係を示す Fig. 6 において引張りあるいは圧縮のひず みが極大となる点 $\mathrm{A}, \mathrm{B}, \mathrm{C}, \cdots \cdots \cdot$...における有効応力の 絶対值 $\left|\sigma_{e}\right|_{\max }$ を片振幅として縦軸にとってある. なお，たと光ば $=1 / 4 \sim 3 / 4$ 間の有効応力および有効

Table I. Chemical composition* and conditions of heat treatment.

\begin{tabular}{|c|c|c|c|c|c|c|c|c|c|c|}
\hline \multicolumn{2}{|c|}{ Material } & C & $\mathrm{S}_{1}$ & Mn & $\mathrm{P}$ & $\mathrm{R}$ & $\mathrm{Cu}$ & $\mathrm{N}$ & $\mathrm{Cr}$ & Heat treatment \\
\hline SS 41 & G & 0.25 & 0.16 & 0.49 & 0.013 & 0.037 & 0.11 & $\operatorname{Tr}$ & 0.02 & $\begin{array}{l}880^{\circ} \mathrm{C}, 30 \mathrm{~min} \\
\text { F.C. }\end{array}$ \\
\hline SS 41 & $\mathrm{E}$ & 0.15 & 0.21 & 0.43 & 0.029 & 0.018 & 0.29 & 0.01 & 0.13 & $\begin{array}{l}890^{\circ} \mathrm{C}, 30 \mathrm{~min} \\
\text { F.C. }\end{array}$ \\
\hline SUS 27 & B & 0.22 & 0.49 & 0.16 & 0032 & 0.006 & - & 8.94 & 19.27 & $\begin{array}{l}1050^{\circ} \mathrm{C}, 2 \mathrm{hr} \\
\text { W.Q. }\end{array}$ \\
\hline SUS 27 & G & 0.09 & 0.69 & 1.22 & 0.029 & 0003 & - & 9.10 & 18.6 . & $\begin{array}{l}1050^{\circ} \mathrm{C}, 2 \mathrm{hr} \\
\text { W.Q. }\end{array}$ \\
\hline
\end{tabular}

* $\%$

Table II. Tensile test results.

\begin{tabular}{|c|c|c|c|c|c|c|}
\hline \multicolumn{2}{|c|}{ Materıals } & Yield strength & Tensile strength & $\begin{array}{l}\text { True breaking } \\
\text { strength }\end{array}$ & Elongation & Reduction of area \\
\hline SS 41 & $\begin{array}{l}\mathrm{G} \\
\mathrm{E}\end{array}$ & $\begin{array}{ll} & 30.0 \\
\text { Upper } & 29.3 \\
\text { I.ower } & 27.5\end{array}$ & $\begin{array}{l}48.6 \\
44.3\end{array}$ & $\begin{array}{l}91.1 \\
83.9\end{array}$ & $\begin{array}{l}31.8 \\
39.7\end{array}$ & $\begin{array}{l}49.5 \\
61.1\end{array}$ \\
\hline SUS 27 & $\begin{array}{l}\text { B } \\
\text { C }\end{array}$ & $\begin{array}{l}25.5 \\
23.6\end{array}$ & $\begin{array}{l}60.3 \\
61.9\end{array}$ & $\begin{array}{c}- \\
210.0\end{array}$ & $\begin{array}{l}68.8 \\
63.9\end{array}$ & $\begin{array}{l}77.3 \\
80.4\end{array}$ \\
\hline
\end{tabular}




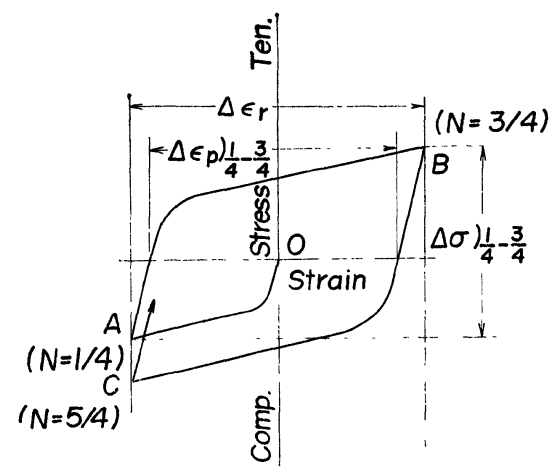

Fig. 6. Strain-stress relationship (Schematic).

ひずみの変化の絶対值を $N=1 / 4 \sim 3 / 4$ 亿対応する応 力全振幅わよび有効塑性ひずみ振幅としてそれぞれ $\left.\left.\Delta \sigma_{e}\right)_{1 / 4 \sim 3 / 4}, \Delta \varepsilon_{p_{e}}\right)_{1 / 4 \sim 3 / 4}$ と書くととにする. Fig. 5 に示されるように SS 41, SUS 27 ともに $N$ の増加 に従がって, 少数の点を除いて, 応力振幅は増加し, $N$ の増加による応力振幅の増加の割合は塑性ひずみ振 幅が大きほど大きかった，塑性ひずみ振幅が小さけれ ば少数回の繰り返しによって応力振幅は安定して, 比 較的大きな回数での変化は小さい.

\section{4 ・2ひずみ振幅之応力振幅}

塑性ひずみ振幅と応力振幅との関係を示したのが Fig. 7 である、ひずみ振幅が大きい場合には応力振

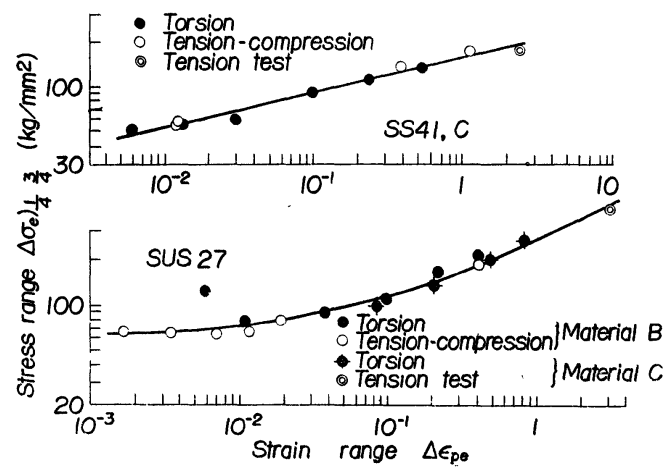

Fig. 7. Relation between $\Delta \varepsilon_{p_{e}}$ and $\left.\Delta \sigma_{e}\right)_{1 / 4 \sim 2 / 4}$.

幅がサイクルとともに急激に変化するので, ぞの $N$ に 対する值を取るかによってての四の関係も大きく変化 するが，Fig. 7 では $N=1 / 4 \sim 3 / 4$ での值が示されて いる. これらの図からわかるように SS 41 では両対 数グラフ上での $\left.\Delta \varepsilon_{p_{e}}\right)_{1 / 4 \sim 3 / 4}$ と $\left.\Delta \sigma_{e}\right)_{1 / 4 \sim 3 / 4}$ との関係が 直線的であって次の(9)式で表わされるが，SUS27では 直線関係は成立していない

$$
\left.\Delta \sigma_{e}=A \Delta \varepsilon_{p_{e}}\right)_{1 / 4 \sim 3 / 4}
$$

SS $41, \mathrm{C}$ 材に対する值は $A=155 \mathrm{~kg} / \mathrm{mm}^{2}, n=0.23$ で あった. Fig. 7 では塑性ひずみ振幅と応力振幅との 関係だけを示したが弾性ひずみと塑性ひずみとを含ん
だ全ひずみ振幅 $\Delta \varepsilon_{r}$ と応力振幅 $\Delta \sigma_{e}$ との関係は弾性 係数がわかればFig. 7 の結果から求められるのでここ では省略する。

\section{4 -3 ひずみ振幅とき裂発生繰返数}

Fig. 8 は有効塑性ひずみ振幅とき裂の発生が認め
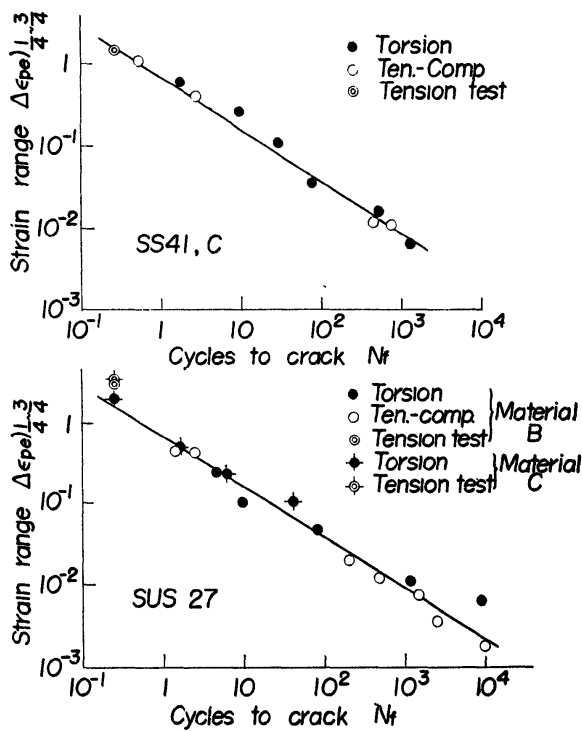

Fig. 8. Relation between $\Delta \varepsilon_{p e}$ and $N_{f}$.

られるまでの繰返数 (き裂発生繰返数) との関係である. き裂発生繰返数は肉眼による観察わよび記録紙上での 荷重またはトルクの減少の過程から判断した巨視的な ものである. Fig. 9 は最大せん断ひずみ振幅とき裂 発生繰返数との関係である.

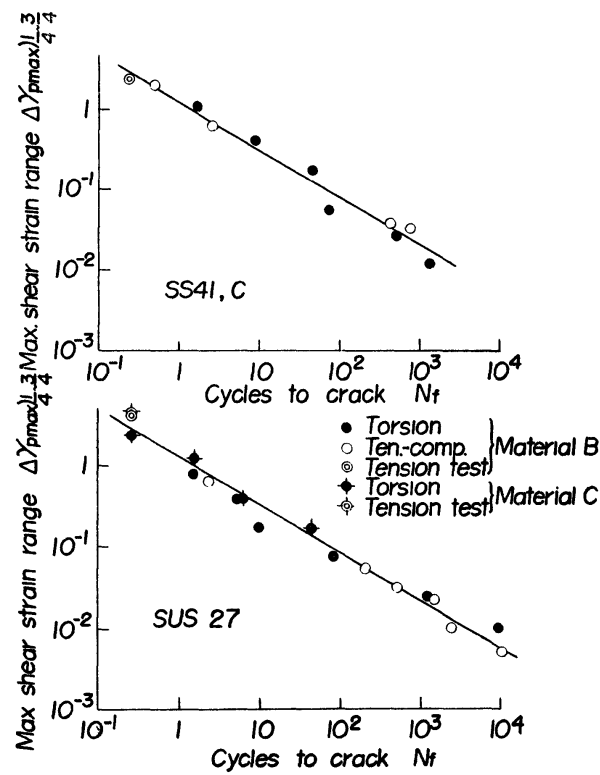

Fig. 9. Relation between $\Delta \gamma_{p \max }$ and $N_{f}$. 
軸荷重のときのき裂は軸と直角方向に発生したが，ね じりの場合仙はき裂が軸方向のみ軸々直角方向のみ， あるいは両方向に生ずる場合があってはっきりした傾 向は判断できなかった。

Fig. 8 および. Fig. 9 に示される結果はいずれも 直線関係であって，次式が成立する。

$$
\begin{gathered}
\left.N_{f}^{a} \Delta \varepsilon_{p_{e}}\right)_{1 / 4 \sim / 4}=K \\
N_{f}^{a \prime} \Delta \gamma_{\left.p_{\max }\right)_{1 / 4 ~ 3 / 4}=k^{\prime}} \\
\text { これらの四に示される直線について } a, a^{\prime}, k, \\
\text { を求めると次のようになる. } \\
\text { SS } 41, C \text { 材では } \quad a=0.64 \quad k=0.66 \\
\quad a^{\prime}=0.60 \quad k^{\prime}=1.21
\end{gathered}
$$

(11)

これらの罒示される直線とついて $a, a^{\prime}, k, k^{\prime}$ の值

SUS $27, B$ 材および

$$
\begin{array}{cll}
C \text { 材では } & a=0.63 & k=0.65 \\
& a^{\prime}=0.59 & k^{\prime}=1.21
\end{array}
$$

SS 41 とUS 27 との間では $a, a^{\prime}, k, k^{\prime}$ の值に事実 上差がないと思われる、 $\Delta \varepsilon_{r}$ と $N_{f}$ との関係はこれら の結果から計算できるので省略する.

引張圧縮試験は常に圧縮から開始した。これは引张 りから始めると，こくに，ひずみ振幅が大きい場合に， 断面が鳳部收縮を起てしたりして練くなるため次の压 縮の過程で座屈するおそれがあるためであった。

このようにするととによって，Fig. 3 の治具を使 用すれば SS 41 では座屈を防ぐてとができたが, SUS 27 では Fig.10 亿例を示すように座屈を生ずる

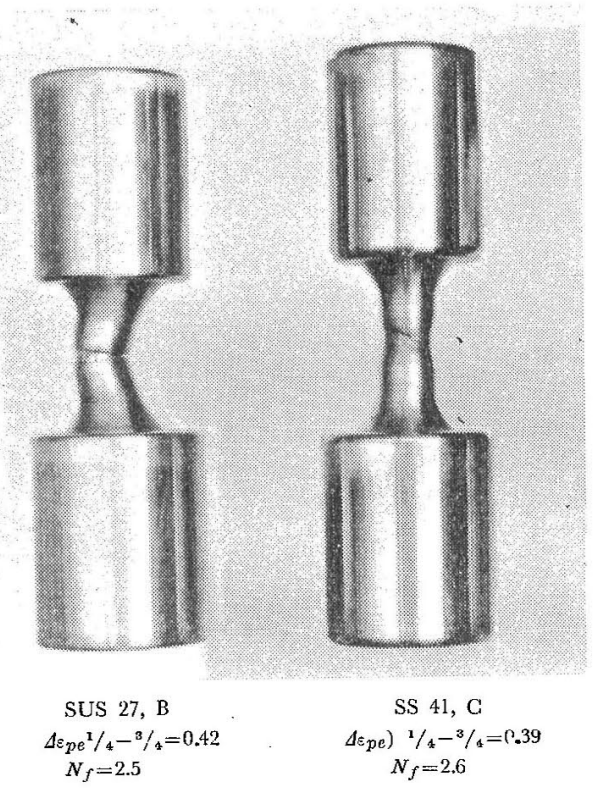

Fig. 10. Tested specimens.

ことがあり，とのためと試験片が漏曲して局部的には 断面積の变化から計算したよりも大きなひずみが， 発生したが， Fig. 8 および Fig. 9 ではてのような 昭和 39 年 8 月
ひずみの集中を然視して破断面でのひずみの平均值が 用いられている。

\section{4・4 ねじり試験結果に及ぼす肉厚の影響}

緒言でも述べたように，高温でのねじり疲学ではき 裂の発生を肉眼で見出すととが困難な場合があり，乙 のときには $N_{f}$ をトルろの急激を減少の椂子から判断 するのが便利であるが，同じ外径の試験片に同し深さ のき裂が発生してを肉厚が厚ければ称じ強さの減少 の割合が小さいのでトルクの減少の状洗から判断され る $N_{f}$ の值は肉厚の大きい場合ほど大きくなりがちで 内径をある。.との点を数值的に確かぬるために而型試 験片で内径 0 〜 $14 \mathrm{~mm}$ 間の種々の值にして定ひずみ水 ビ疲労試験を行なった。 Fig. 11 はその際のトルクの

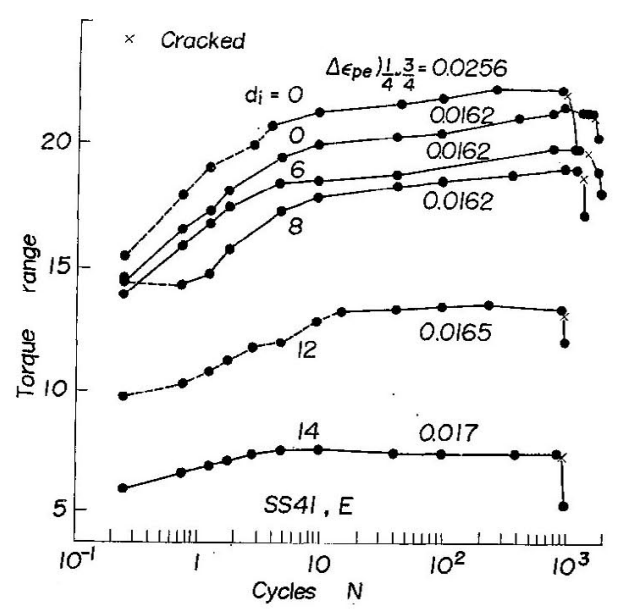

Fig. 11. Variation of torque during tests of specimens with various thickness.

繰返往って変化であって，外表面での有效望性ひず み振幅 $\Delta \varepsilon_{p e}$ が付記してある。 $\Delta \varepsilon_{p e}$ はできるだけ一定 としたが, ある程度の差はま始かれなかったので, 肉厚 が暴なっても $\Delta \varsigma_{p_{e}}$ と $N_{f}$ との関俰が(10)式の形で表わせ てしが $a$ 亿は肉厚の影響がすいものとして $\Delta \varepsilon_{p e 1 / 4 \sim}$

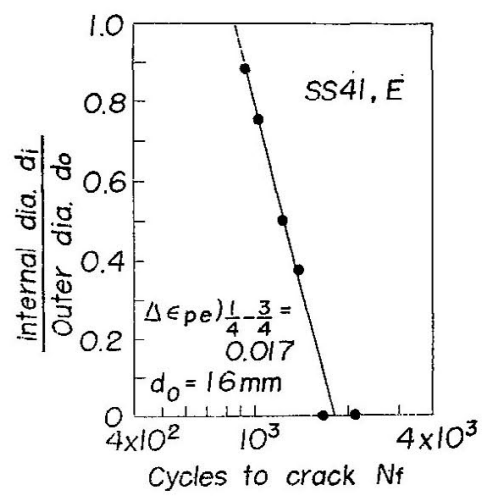

Fig. 12. Effect of thickness of specimen to $N_{f}$. 
${ }_{3 / 4}=0.017$ 亿対する值に補正して $N_{f}$ を求め, 内外径 の比と $N_{f}$ との関係を図示すると Fig. 12 のように なった，同図上の両者の関係は直線的であって，中実 試験片の $N_{f}$ は肉厚が $1 \mathrm{~mm}$ 程度のときの約 2 倍であ る.

\section{5 結言}

以上の結果をまとめると次のととが言える.

(1) 実験の範囲では, 塑性有効ひずみ $\varepsilon_{p e}$ を用いれば ねじりと引張圧縮いずれの定ひずみ疲学試験における 応力振幅, ひずみ振幅, き裂発生繰返数間の関係も試 験方法に関係なく共通に整理できるととが確認された。 (2) 最大せん断塑性ひずみ振幅 $\Delta \varepsilon_{p \max }$ と $N_{f}$ との間 亿も塑性ひずみ振幅 $\Delta \varepsilon_{p e}$ と $N_{f}$ との関係式(10)飞類似 した(11)式が試験方法と関係なく成立するととが認めら れた。

(3) 室温で行なった本実験の範团では $\Delta \varepsilon_{p_{e}}$ もしくは
$\Delta \gamma_{p_{\max }}$ と $N_{f}$ との関係で示される強度にっいて SS 41 と SUS 27 との間に差はほとんぞ認められなかった。 (4) 定ひずみねじり疲労試験でトルクの減少によって $N_{f}$ を判定する場合には試験片の肉厚の影響がかなり あるので注意しなければならない.

最後に本研究を行なうにあたって多大ので助力をい ただいた日立製作所日立工場の各位，当所大内田主任: 研究員に厚くお礼を申し上げるとともに実験を遂行さ れた照沼，津村両氏に心から謝意を表する次第である。 (昭和38年11月 8 日，塑性疲労および熱疲学に関する坐、炎会にて講演）

\section{参考文 献}

1)たとえば, Monson, S.S., Machine Design, 142 (1960).

2) Nada, A., "Theory of Flow and Fracture of Solids," Chapt. 12, (1950) McGraw-Hills. 